\title{
ARTICLE
}

\section{Evaluation of a silver-ion based purification system for rainwater harvesting at a small-scale community level}

\author{
I. Adler*, K. A. Hudson-Edwards** and L. C. Campos* \\ ${ }^{*}$ Civil, Environmental and Geomatic Engineering, University College London, \\ Gower Street, London WC1E 6BT, UK \\ (E-mail: ilan.adler.09@ucl.ac.uk; l.campos@ucl.ac.uk) \\ ${ }^{\star *}$ Dept. of Earth and Planetary Sciences, Birkbeck, University of London, \\ Malet Street, London WC1E 7HX, UK \\ (E-mail:k.hudson-edwards@bbk.ac.uk)
}

\begin{abstract}
Silver has been known for centuries to be a powerful disinfectant, with no known harmful effects to humans if applied in adequate doses. Although its use was partially discontinued with the advent of chlorination and modern antibiotics, the discovery of bacterial resistance and disinfection byproducts has enabled its re-emergence as a viable water purification option. On the other hand, implementation in small-scale rainwater harvesting systems has received little attention, possibly due to a general perception that it is a complex and/or expensive technology. This can be overcome by efficient designs that dose silver ions into the water at a minimal cost. The authors evaluated a dozen rainwater harvesting systems equipped with silver releasing devices, which have been providing drinking water to schools and clinics in a rural area of Mexico. This paper represents a follow-up to a previously published study on an evaluation performed in the same region. A number of water quality parameters have been analysed, examining the long-term efficiency of the projects. Our observations show that the silver ion devices act as an effective disinfection mechanism, as long as adequate maintenance is provided. The combination with conventional settling tanks and filtration units seems to greatly enhance the overall performance of the system.
\end{abstract}

KEYWORDS: disinfection, drinking water, rainwater harvesting, sustainable development, silver ions

\section{BACKGROUND}

It is a well-established fact that access to drinking water is fast becoming one of the paramount challenges of the new millennium, particularly in developing countries where population growth and environmental pressures are highest. Abundant literature suggests that rainwater harvesting 
(RWH) can be utilized as a sustainable and practical solution, as long as proper design and water quality issues are taken into consideration (Ward et al. 2010). This paper follows up on a previous study (Adler et al. 2011), where 9 Mexican rural communities located in the San Miguel de Allende Municipality, equipped with RWH systems for drinking water provision, were monitored for basic water quality parameters and performance indicators. The systems followed the same general design and contained similar components, with minor individual variations according to size and volume requirements, thus allowing for comparison between them. These were installed in each community, at the local primary schools or clinics, between 2007 and 2009. The silver ionising devices were installed in 2009, towards the end of this period. The general system design is outlined in the schematic figure below.

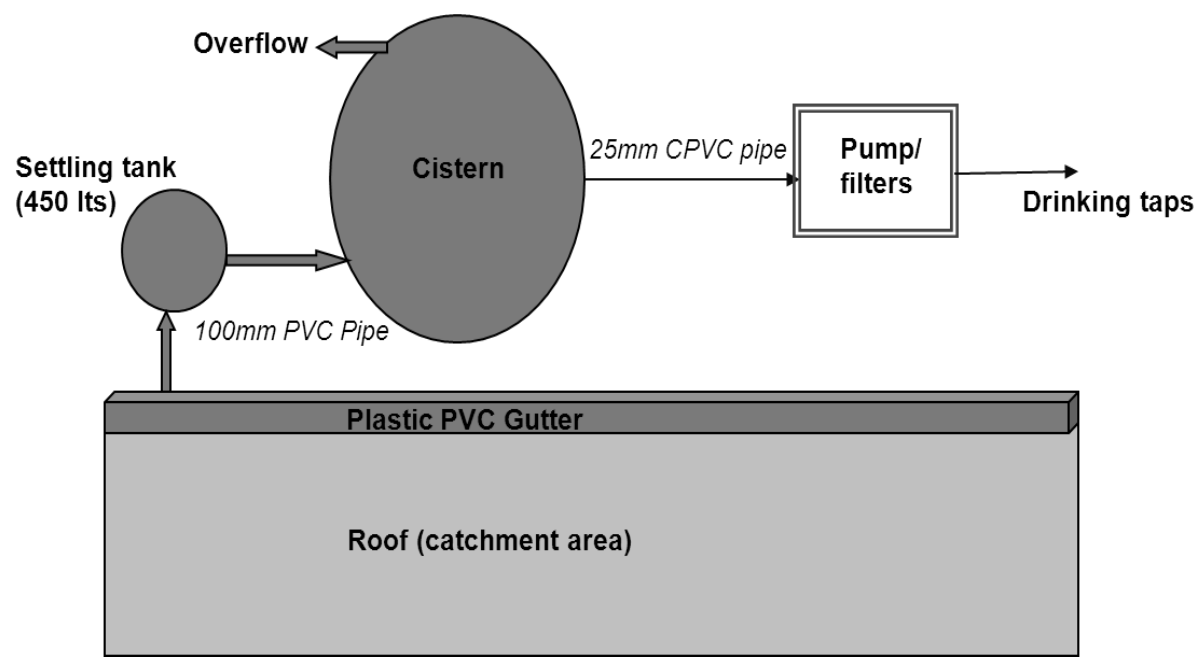

Fig. 1. System design showing main components (not to scale)

In summary, every RWH installation being studied contains the following components:

1. Rooftop and guttering

2. First-flush/ settling tank

3. Storage Cistern (usually made of hard HDPE plastic or geomembrane)

4. Conventional filtration, including stainless steel mesh and activated carbon (GAC)

5. Silver ionising unit, described below, one of the key components of the system.

The present study consisted on evaluating the projects after more than 2 years from the initial assessment, applying similar field techniques and data processing tools, albeit with additional parameters added based on our previous experience. Results were analysed and compared with the original data set, obtaining further insights on both the silver-ion system and the installation as a whole. Our focus was on system performance and not on the incoming rainwater quality per se, which tends to vary seasonally along with a number of complex factors such as weather and air quality (Evans et al. 2006; Kaushik et al. 2012). Although both studies were started in different periods (April 
2010 and September 2012), this in itself would not present enough data for a proper time variability evaluation.

\section{MATERIALS AND METHODS}

\section{Characteristics of the silver-ion device}

The devices, supplied by SilverLife, consist of a pair of silver electrodes, which are activated by an alternating DC voltage, changing polarity at a fixed rate of every 10 seconds (approx.) so as to get an even wear on each electrode. They are placed in line with the filtering system, after a 100 micron stainless steel mesh filter (to remove larger particles) and before the activated carbon filter, which is responsible for removing colour, odour and other major contaminants. Water is thus treated at 'point of use', although some silver residual remains for long enough to ensure that the pipelines are not contaminated, as shown in the results.

Table 1. Sampling point description

\begin{tabular}{|l|l|l|}
\hline ID & Point & Sampling notes \\
\hline 1 & Settling tank & From plastic sedimentation tanks; corresponding to roof runoff \\
\hline 2 & Cistern & $\begin{array}{l}\text { In over-ground tanks sample was taken from a valve (5-10 cm } \\
\text { above the bottom); in underground cisterns, it was taken from } \\
\text { the suction of the pump, located roughly 20-30 cm over the } \\
\text { bottom }\end{array}$ \\
\hline 3 & Silver ioniser & $\begin{array}{l}\text { From a sampling point located between the silver ioniser and } \\
\text { the activated carbon/fine particle filters }\end{array}$ \\
\hline 4 & Drinking tap & $\begin{array}{l}\text { From drinking water fountains, usually let to run for at least 1 } \\
\text { min before sampling to remove any stagnant water remaining } \\
\text { on pipes }\end{array}$ \\
\hline
\end{tabular}

\section{Field analyses}

Basic water quality parameters such as $\mathrm{pH}$, conductivity and temperature were obtained on site. Other analyses such as microbiology were performed at SAPASMA (acronym for the Municipal Water Authority of San Miguel de Allende) in the water quality lab that serves the town's main water treatment plant, usually on the same day when samples were collected.

Samples were collected from September to October 2012 (after the start of the rainy season) as part of a UCL-coordinated research project. A total of 10 sites were analysed (Table 3), with 4 distinct sampling points throughout each system, corresponding to the main stages of the purification process. Duplicates were taken from selected samples wherever logistically possible. 
Table 2. Equipment and methods used according to parameter

\begin{tabular}{ll}
\hline $\mathrm{pH}$ & Orion Aplus portable PH/ISE Meter \\
Conductivity & Portable ECTestr meter: low range $(0-1900 \mu \mathrm{S})$ \\
Coliforms & Hach m-ColiBlue24® (Membrane Filtration method) \\
COD & Hach DR2800 Spectrophotometer \\
Silver & ICP-MS \\
Hardness/ Alkalinity & Titration, according to Standard Methods \\
Dissolved Oxygen/ & Hach sensION 6 DO meter \\
Temp. & \\
Cations & Jobin Yvon Ultima 2 ICP-OES \\
Anions & Dionex lon Chromatograph \\
Silver & Varian 820-M ICP-MS \\
TOC & Shimadzu TOC-L Analyser \\
\hline
\end{tabular}

\section{Laboratory tests}

Two sets of samples were collected from every site for shipping back to the UK, with the purpose of performing more in-depth analyses. The first was for anions and TOC, which were analysed on a Dionex Ion Chromatograph and a Shimadzu TOC analyser respectively. The second sample was acidified using ultra-pure nitric acid $(2 \%)$ for conservation purposes. This one was used to detect major cations as well as silver ion concentrations, performed with an ICP-OES and an ICP-MS, respectively. Both samples were collected in new $30 \mathrm{~mL}$ plastic bottles, specifically designed for the analysis of trace metals, filled to the top so as to avoid air bubbles, and stored constantly under refrigeration. Transport was done in cooler boxes using express courier services so as to minimize any variability due to changes in temperature.

Table 3. Rainwater harvesting systems used for study 


\begin{tabular}{|c|c|c|c|c|c|}
\hline ID & Community/sampling site & $\begin{array}{l}\text { Roof } \\
\text { area } \\
\left(\mathrm{m}^{2}\right)\end{array}$ & $\begin{array}{l}\text { Consumption } \\
\text { (m³/year) }\end{array}$ & $\begin{array}{l}\text { Cistern } \\
\text { type* }\end{array}$ & $\begin{array}{l}\text { Cistern } \\
\text { size }\left(\mathrm{m}^{3}\right)\end{array}$ \\
\hline 1 & $\begin{array}{l}\text { Rancho Nuevo Villa } \\
\text { Guadalupe }\end{array}$ & 80 & 10.0 & TK & 5 \\
\hline 2 & Boca de la Cañada & 140 & 28.0 & OG & 17 \\
\hline 3 & Don Juan & 49 & 8.0 & OG & 7.5 \\
\hline 4 & La Aurora & 60 & 8.8 & TK & 10 \\
\hline 5 & $\begin{array}{l}\text { San Miguel Viejo - } \\
\text { Classroom }\end{array}$ & 98 & 32.0 & OG & 45 \\
\hline 6 & San Miguel Viejo - Kitchen & 60 & 16.0 & UG & 17 \\
\hline 7 & Augustin Gonzalez - Clinic & 140 & NA & UG & 45 \\
\hline 8 & Augustin Gonzalez - School & 350 & 48.0 & UG & 80 \\
\hline 9 & El Salitre & 200 & 30.0 & OG & 17 \\
\hline 10 & Montecillo de Nieto & NA & NA & OG & 30 \\
\hline
\end{tabular}

Notes: Systems are all installed in schools in the respective communities, except for (\#7), which is in a rural clinic. * OG - Overground geomembrane; UG - buried/underground cistern with geomembrane liner; TK -pre-fabricated plastic tanks (5,000 L) with lids); NA - not available.

\section{RESULTS AND DISCUSSION}

Table 3 summarizes general data from the communities and systems sampled. Roofs are made of concrete, coated with an asphalt-based paint for waterproofing known by its brand name 'Fester' (manufactured by Henkel in Mexico). The only exception to this was site \#1 (Rancho Nuevo), which has an asbestos roof. The overall conditions of each catchment surface were found to be highly variable. In some cases the waterproof coating was intact, in others it looked worn and badly in need of repair. One more site (No. 2), which was unavailable for sampling in 2010, was added to the present study.

\section{Field parameters}

Table 4 summarizes results obtained from main parameters analysed throughout the different sites and sampling points. 
Conductivity in general terms was found to be low (in the range of $20-70 \mu \mathrm{S} / \mathrm{cm}$ ) in the settling tanks, as is to be expected from rainwater, which tends to have low dissolved solids. Conductivity increased sharply, however, in most systems at the tap or drinking water point, possibly due to the effect of the silver ionisation. COD was found to be moderate in the settling tanks and cisterns (10$40 \mathrm{mg} / \mathrm{l}$ ) but was practically eliminated after passing through the purification system. TOC followed a similar pattern (Fig. 2). Alkalinity values, on the other hand, tended to remain quite constant throughout the treatment process, but varied greatly within individual systems $(10-80 \mathrm{mg} / \mathrm{l})$, possibly due to variations in roof composition. The leaching of calcium carbonate from poorly maintained concrete roofs, could be a potential cause for increase (Morrow et al. 2010). The same applied to hardness, which was closely correlated to the alkalinity values.

$\mathrm{PH}$ was found to be close to neutral, and showed no significant variation throughout the different stages. The lowest value detected was 5.66 in one of the settling tanks, possibly due to the decomposition of leaves and the formation of humic acids (Meera \& Ahammed 2006; Yaziz et al. 1989). The $\mathrm{pH}$ at the drinking tap was found to be above 6.2, which is in compliance with Mexican drinking water guidelines (Secretaría de Salud 1994). Water temperatures were all in the range of $20^{\circ} \mathrm{C}$.

Flow rates measured at the drinking water tap were an average of $1 \mathrm{~L} / \mathrm{min}$, except in San Miguel Viejo (site No. 5) where values were slightly lower since this system is gravity-fed by an elevated tank, instead of a pressure pump like the other sites.

Table 4. Main field parameters (sampling point in brackets)

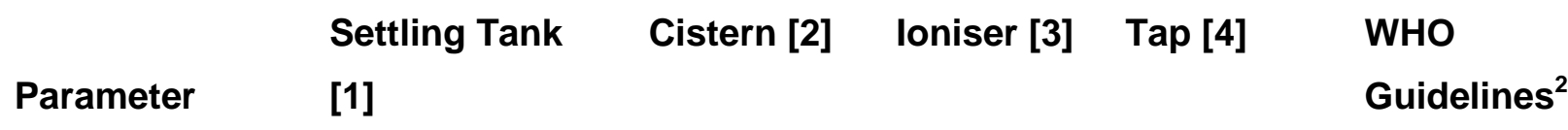

\begin{tabular}{llllll}
\hline Temp $\left({ }^{\circ} \mathrm{C}\right)$ & $19.1(0.5)^{1}$ & $19.5(0.4)$ & $17.6(0.7)$ & $19.4(1.1)$ & NA \\
$\mathrm{pH}$ & $6.4(0.1)$ & $6.9(0.2)$ & $6.6(0.2)$ & $6.8(0.1)$ & $6.5-8.5$ \\
$\begin{array}{l}\text { Conductivity } \\
(\mu \mathrm{S} / \mathrm{cm})\end{array}$ & $43(5.4)$ & $138.2(40.2)$ & $100(38.1)$ & $145(48.6)$ & 250 \\
$\mathrm{DO}(\mathrm{mg} / \mathrm{l})$ & $5.1(0.3)$ & $5.5(0.2)$ & $5(0.4)$ & $4.8(0.3)$ & $\mathrm{NA}$ \\
$\mathrm{COD}(\mathrm{mg} / \mathrm{l})$ & $14.4(2.8)$ & $8.6(2)$ & $13.5(4)$ & $2.3(1.1)$ & $\mathrm{NA}$ \\
Alkalinity $(\mathrm{mg} / \mathrm{l})$ & $18.5(1.9)$ & $32.7(5.6)$ & $20.3(3.9)$ & $27.8(4.6)$ & $\mathrm{NA}$
\end{tabular}




$\begin{array}{llllll}\text { Hardness }(\mathrm{mg} / \mathrm{l}) & 23.5(2.9) & 40.4(7) & 25.6(4.4) & 42.3(5.9) & 500 \\ \text { TOC (ppm) } & 5.8(2.04) & 2.9(0.5) & 2.4(0.5) & 1.8(0.6) & \mathrm{NA}^{3} \\ \mathrm{Ag}+(\mathrm{ppb}) & \text { NA } & 9.9(3.4) & 9.3(5.7) & 8.2(3.6) & \mathrm{NA}^{4}\end{array}$

1. Standard error of the mean (SEM) cited in parenthesis. Maximum $\mathrm{N}=22$, including repeats collected on different dates. Where a specific sampling point was unavailable, the corresponding $\mathrm{N}$ value was reduced.

2. From WHO (2011). Values shown are considered 'desirable' rather than maximum limits. NA: Not applicable (i.e. parameter for which guideline values have not been established). 3. Guidelines only set where chlorination is used as a disinfectant, as TOC can be closely correlated to disinfection by-products (US EPA 2006). It is not applicable in this case.

4. The latest WHO drinking water standards (2011) do not establish any guideline value for silver, proving the case that it is not considered a substance of particular concern for health. The limit adopted by some water agencies of 100 ppb is merely a desirable target (WHO 2008).

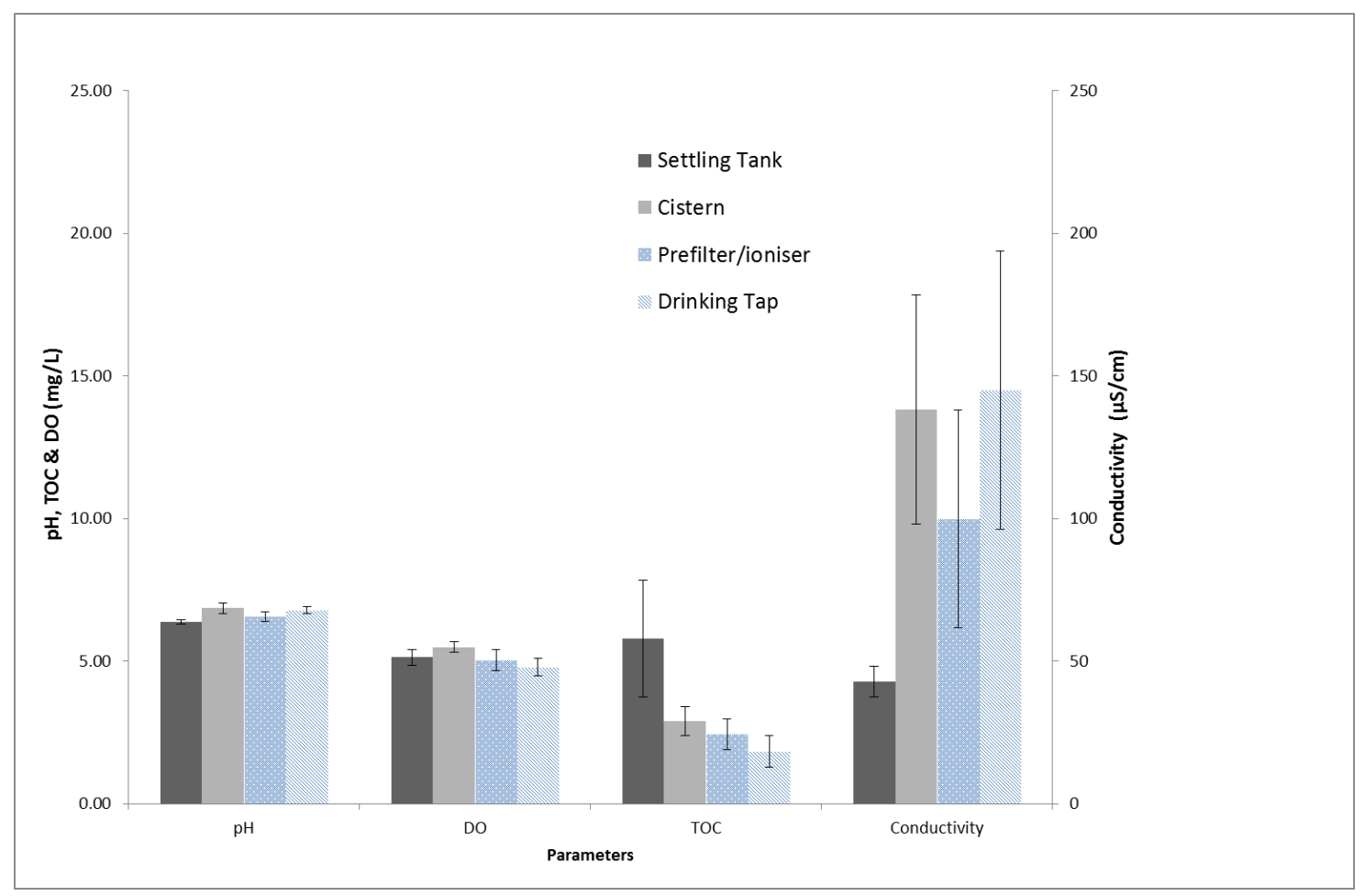

Fig. 2. Comparison of selected field parameter means at each of the sampling points (Table 4).

\section{Disinfection}

Faecal coliforms, E. coli and Total Coliform counts were used as microbiological indicators, due to their ease of detection and their acceptance in most drinking water guidelines worldwide. The authors accept, however, the limitations inherent in this, a discussion beyond the scope of the present paper (Gleeson \& Gray 1996). Analysis was done using the Hach Colliblue method, according to standard analytical procedures (Crane et al. 2006; APHA 2005). 
As expected, and according to our previous study (Adler et al. 2011), settling tanks tend to have a high coliform count, sometimes over $1,000 \mathrm{CFU} / 100 \mathrm{~mL}$ for total counts, and corresponding lower counts for $E$. coli (maximum value detected was $275 \mathrm{CFU} / \mathrm{mL}$ ). However, after passing through the entire filtration and silver ionising system, counts were consistently reduced to zero, making the water safe for human consumption. Settling in itself tended to reduce bacterial counts (Fig. 3), which is in agreement with other studies performed on settling tanks and first flush systems, but did not account for a total elimination, justifying the need for additional filtration and disinfection.

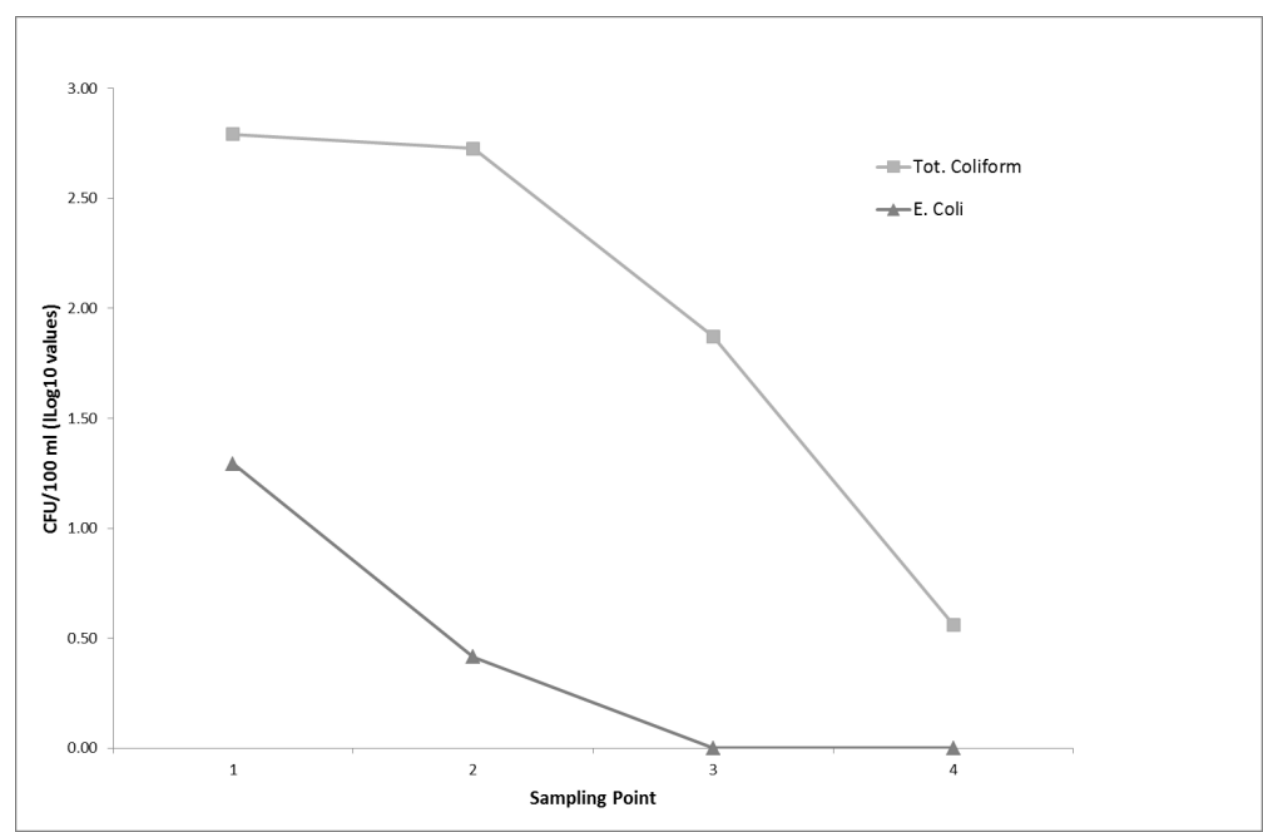

Fig. 3. Reduction of average total coliforms and $E$. coli throughout the different sampling points (Table 1). Microbiological indicators are expressed as Log10 values.

\section{Silver ions and chemical composition}

Silver has been used for a long period of time in different contexts as a disinfectant (Landau 2007) with considerable bacteriostatic properties but has not, to the authors' knowledge, been properly tested on functional RWH systems such as these. Silver is not known to be harmful nor toxic to human beings in the amounts dosed here, detected on all final drinking water points to be well below the 100 ppb target set by local and international drinking water guidelines (WHO 2008; Secretaría de Salud 2000), with a maximum reading of $57 \mathrm{ppb}$, and average values around $10 \mathrm{ppb}$ (see Table 4). Recent controversy regarding the release of silver ions into the environment is mostly related to the use of nanoparticles in high concentrations (Khaydarov et al. 2009; Wijnhoven et al. 2009), and is not considered to be particularly relevant to the small-scale application being studied. Some silver was also found to 'backflow' into the cisterns, providing extra protection from recontamination. 
Furthermore, in two of the systems electricity had been off for a few days, thus not allowing additional silver to be injected into the system by the ionising device. In both cases, small amounts of residual silver were still found, which is in agreement with previous experiments pointing to the fact that silver, where there is a relatively low amount of other precipitating ions, can stay active in water for an extended period of time (Landau 2007).

Finally, chemical anions and cations (see Table 5) were present in low concentrations throughout, with the highest anions being nitrate and sulphate, possibly due to atmospheric precipitation of acid compounds (Appelo \& Postma 2005). Correspondingly higher concentrations of total sulphur were also recorded, as expected from rainwater. Calcium and sodium were also slightly higher than other cations, most likely due to the concrete roofs and the corresponding increase in hardness, as explained above.

Table 5. Selected cation and anion concentrations ( $\mathrm{mg} / \mathrm{l})$

\begin{tabular}{|c|c|c|c|c|c|c|}
\hline \multirow[b]{2}{*}{$\begin{array}{l}\text { Paramete } \\
r\end{array}$} & \multicolumn{2}{|c|}{ Settling Tank } & \multicolumn{2}{|l|}{ Cistern } & \multicolumn{2}{|c|}{ Drinking Tap } \\
\hline & Range & Mean $^{1}$ & Range & Mean & Range & Mean \\
\hline & & & & 0.37 & & \\
\hline \multirow[t]{2}{*}{$\mathrm{F}$} & $0-0.97$ & $0.2(0.1)$ & $0-1.92$ & $(0.16)$ & $0-2.34$ & $0.6(0.3)$ \\
\hline & $0.51-$ & & $0.29-$ & 3.61 & $0.5-$ & \\
\hline \multirow[t]{2}{*}{$\mathrm{Cl}$} & 4.74 & $1.88(0.47)$ & 12.51 & (1.22) & 13.68 & $3.6(1.7)$ \\
\hline & & & $0.19-$ & 10.94 & & \\
\hline \multirow[t]{2}{*}{$\mathrm{NO}_{3}$} & $0-19.81$ & $5.51(1.94)$ & 27.63 & (2.92) & $0-41.08$ & $10.4(5.3)$ \\
\hline & & & & 1.42 & & \\
\hline \multirow[t]{2}{*}{$\mathrm{PO}_{4}$} & $0-2.13$ & $0.74(0.28)$ & $0-9.58$ & $(0.84)$ & $0-0.78$ & $0.2(0.1)$ \\
\hline & $0.48-$ & & $1.46-$ & 10.8 & $4.98-$ & \\
\hline \multirow[t]{2}{*}{$\mathrm{SO}_{4}$} & 29.7 & 8.94 (3.39) & 21.89 & (2.14) & 23.5 & $11.8(2.2)$ \\
\hline & $0.61-$ & & $2.36-$ & & $2.16-$ & \\
\hline \multirow[t]{2}{*}{$\mathrm{Ca}$} & 12.57 & $5.01(1.26)$ & 21.43 & 9.6 (1.59) & 23.7 & $10.5(1.6)$ \\
\hline & $0.13-$ & & $0.24-$ & 3.74 & $0.58-$ & \\
\hline $\mathrm{K}$ & 3.89 & $0.81(0.35)$ & 9.77 & $(1.16)$ & 9.3 & $3.7(0.8)$ \\
\hline
\end{tabular}




\begin{tabular}{|c|c|c|c|c|c|c|}
\hline \multirow[b]{2}{*}{$\mathrm{Mg}$} & \multicolumn{2}{|l|}{$0.05-$} & \multirow{2}{*}{$\begin{array}{l}0.16- \\
11.16\end{array}$} & \multicolumn{2}{|l|}{1.75} & \multirow[b]{2}{*}{$1.2(0.3)$} \\
\hline & 0.23 & $0.14(0.02)$ & & $(0.99)$ & $0.2-3.8$ & \\
\hline \multirow{3}{*}{$\mathrm{Na}$} & \multirow{3}{*}{$0.0-3.0$} & \multirow{3}{*}{$0.55(0.34)$} & \multirow{3}{*}{$0.0-53.6$} & 12.83 & $0.0-$ & \multirow{3}{*}{$11(5.1)$} \\
\hline & & & & $(5.74)$ & 56.32 & \\
\hline & & & & 0.03 & $0.0-$ & \\
\hline \multirow[t]{2}{*}{$P$} & $0.0-0.3$ & $0.05(0.03)$ & $0.0-0.08$ & $(0.01)$ & 0.46 & $0.1(0)$ \\
\hline & $0.44-$ & & $0.95-$ & 3.07 & $0.94-$ & \\
\hline$S$ & 2.76 & $1.11(0.24)$ & 7.28 & $(0.69)$ & 16.9 & $4.3(1.1)$ \\
\hline
\end{tabular}

\section{CONCLUSIONS}

The experimental results obtained confirm that the system along with all its components, including settling tank, filters and silver ioniser, has the potential to provide quality drinking water from harvested rain, as long as reasonable and routine maintenance is performed, coinciding with conclusions from our previous study (Adler et al. 2011). Future research would benefit from additional sampling rounds at different times of the year, in order to better understand potential seasonal variations. Improvements in the quality of the data obtained could also be achieved by faster and more localised testing, reducing any errors inherent in conserving and transporting samples across long distances. The isolated performance of the silver ioniser also needs to be accurately determined. Our research group at UCL is currently testing a variety of laboratory-scale models with this purpose in mind, as well as methods for improving the efficiency of the overall system, which are due to be published in the near future. We are also in the process of testing the performance of the device using other microorganisms that could be more resilient than bacteria, such as viral indicators.

\section{ACKNOWLEDGEMENTS}

The authors would like to thank the Water Authority of San Miguel (SAPASMA), the helpful personnel at the municipal wastewater treatment plant, and the local Environment \& Ecology Department (DMAE), in particular Denia Gonzalez, Ernesto and Misael, for making this study possible. We are also 
particularly grateful to Rachel Smith for the collection of the samples and onsite testing, as well as the helpful team of Origen San Miguel, mainly Werner, Victor, Jesus and Gaby. 


\section{REFERENCES}

Adler, I., Hudson-Edwards, K.A. \& Campos, L.C., 2011. Converting rain into drinking water: quality issues and technological advances. Water Science \& Technology: Water Supply, 11(6), p.659. Available at: http://www.iwaponline.com/ws/01106/ws011060659.htm [Accessed January 8,2012$]$.

APHA, 2005. Standard Methods for the Examination of Water \& Wastewater 21st ed. Andrew D. Eaton et al., eds., American Public Health Association.

Appelo, C.A.J. \& Postma, D., 2005. Geochemistry, groundwater and pollution 2nd ed., Leiden $\square ;:$ Balkema.

Crane, R. et al., 2006. EPA Approves New Test Procedures for the Analysis of Microbiological Pollutants in Wastewater and Sludge, Loveland, CO, USA. Available at: www.hach.com.

Evans, C.A., Coombes, Peter J \& Dunstan, R.H., 2006. Wind, rain and bacteria: The effect of weather on the microbial composition of roof-harvested rainwater. Water Research, 40(1), pp.37-44. Available at:

http://www.ncbi.nlm.nih.gov/entrez/query.fcgi?db=pubmed\&cmd=Retrieve\&dopt=AbstractPlus \&list_uids=000235045700004.

Gleeson, C. \& Gray, N., 1996. Coliform Index and Waterborne Disease, London: Spon Press. Available at: http://www.amazon.com/Coliform-Index-Waterborne-DiseaseGleeson/dp/041921870X [Accessed November 23, 2010].

Kaushik, R., Balasubramanian, R. \& De la Cruz, A.A., 2012. Influence of air quality on the composition of microbial pathogens in fresh rainwater. Applied and environmental microbiology, 78(8), pp.2813-8. Available at: http://aem.asm.org/cgi/content/abstract/78/8/2813 [Accessed March 27, 2012].

Khaydarov, R.R. et al., 2009. SILVER NANOPARTICLES Environmental and Human Health Impacts. Nanomaterials Risks and Benefits, pp.287-297 472.

Landau, U., 2007. Bactericidal and Oligodynamic Action of Silver and Copper in Hygiene, Medicine and Water Treatment, Finishing Publications Ltd. Available at: http://www.amazon.com/Bactericidal-Oligodynamic-Hygiene-MedicineTreatment/dp/0904477304 [Accessed November 23, 2010].

Meera, V. \& Ahammed, M., 2006. Water quality of rooftop rainwater harvesting systems: A review. Journal of Water Supply: Research and Technology-AQUA, 55(4), pp.257-268.

Morrow, A.C., Dunstan, R.H. \& Coombes, P J, 2010. Elemental composition at different points of the rainwater harvesting system. Science of the Total Environment, 408(20), pp.4542-4548.

Secretaría de Salud, 2000. Modificacion a la Norma Oficial Mexicana NOM-127-SSA1-1994, Salud ambiental. Agua para uso y consumo humano, Mexico.

Secretaría de Salud, 1994. Norma Oficial Mexicana NOM-127-SSA1-1994 "Salud Ambiental, Agua para uso y consumo humano-limites permisibles de calidad y tratamientos a que debe someterse el agua para su potabilizacion", Mexico. Available at: http://www.salud.gob.mx/unidades/cdi/nom/127ssa14.html.

US EPA, 2006. Stage 2 Disinfectants and Disinfection Byproduct Rule, USEPA. Available at: http://water.epa.gov/lawsregs/rulesregs/sdwa/stage2/index.cfm [Accessed July 11, 2013]. 
Ward, S., Memon, F.A. \& Butler, D., 2010. Harvested rainwater quality: The importance of appropriate design. Water Sci. Technol., 61(7), pp.1707-1714. Available at:

http://www.scopus.com/inward/record.url?eid=2-s2.0-

77953372165\&partnerID=40\&md5=60c95bd723c237300aa12df86e83c2ec.

WHO, 2011. Guidelines for Drinking-water Quality 4th ed., Geneva: World Health Organization. Available at:

http://www.who.int/water_sanitation_health/publications/2011/dwq_chapters/en/index.html.

WHO, 2008. Guidelines for Drinking-water Quality 3rd ed., Geneva: World Health Organization. Available at: http://www.who.int/water_sanitation_health/dwq/fulltext.pdf [Accessed December 1, 2010].

Wijnhoven, S.W.P. et al., 2009. Nano-silver - a review of available data and knowledge gaps in human and environmental risk assessment. Nanotoxicology, 3(2), pp.109-138. Available at: http://informahealthcare.com/doi/abs/10.1080/17435390902725914 [Accessed March 7, 2013].

Yaziz, M.l. et al., 1989. Variations in rainwater quality from roof catchments. Water Research, 23(6), pp.761-765. Available at: http://dx.doi.org/10.1016/0043-1354(89)90211-X [Accessed January 13, 2011]. 